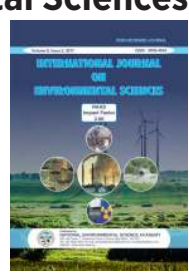

\title{
CONSTRUCTED WETLANDS FOR MUNICIPAL WASTEWATER TREATMENT: A SUSTAINABLE APPROACH
}

\author{
Monali Mudulia ${ }^{1,2}$ and Sanak Ray ${ }^{1,2^{*}}$ \\ ${ }^{1}$ Analytical and Environmental Science Division \& Centralized Instrument Facility, CSIR-Central Salt \& \\ Marine Chemicals Research Institute, G.B. Marg, Bhavnagar-364002, Gujarat, India \\ ${ }^{2}$ Academy of Scientific and Innovative Research (AcSIR), Ghaziabad-201002, Uttar Pradesh, India
}

\author{
Research Article
}

Received: 17.07.2021

Accepted: 28.08.2021

Published: 10.09.2021

\begin{abstract}
Water, the most valuable gift of nature is at a critical stage so called pollution, due to intense industrialization, urbanization and exponential population growth. Thus, a diagnosis that has the potential to cure that critical stage of water with no harmful impact on the other elements of nature is an utmost requirement now a days. Tremendous development in the field of research has suggested a number of treatment methods to get over water pollution. Constructed wetland (CW) an engineered unit that follows bio-geochemical approaches to heal the polluted stage of water with a significant pollutant removal efficiency, has stood first in the field of sustainable water treatment and technology. Not only water treatment through an eco-friendly manner but also creating an ecosystem with in that working area with aesthetic and economical production are the major reasons behind the popularity of this system. Selection of vegetation, substrate and construction of that system at a proper location are the limitation of constructed wetland. In this system sedimentation, filtration and adsorption through substrate, neutralization, and precipitations, phyto-accumulation of plant species and microbial remediation by microorganisms present in the rhizospheres of plants etc. are the processes that supports the treatment activity. This paper discusses various types of constructed wetlands and their mechanism and performance intended for municipal wastewater treatment. Besides it the paper covers the discussion regarding reusability of the treated water.This paper will help promote the wastewater treatment using CWs and further help to design and develop innovative hybrid technologies for sustainable wastewater treatment.
\end{abstract}

Keywords: Constructed wetland; Municipal wastewater; Waste treatment; Removal efficiency; Reusability.

\section{INTRODUCTION}

Water pollution is one of major difficulties that the entire world is facing recently after global warming. It has been reported, keeping view on the huge population growth with changing lifestyle and rapid urbanization and industrialization that the volume of wastewater will increase by $30 \%$ by 2030 and $51 \%$ by 2050 from the existing volume. So, it is a carry-on call to us to be attentive and prepared for the wastewater treatment and reuse of that water for various purposes otherwise it will cause a severe water crisis in future (Qadir et al., 2020).
Municipal wastewater is one of the major contributors to this big issue that has made whole world alert about water security, conservation, wastewater treatment for reuse purposes. Basically, municipal wastewater is nothing but a blend of residential and commercial zone run off with minor contribution of infiltration from the subsoil (Gilmour \& Zimmerman, 2020). Major components of municipal wastewater are suspended and dissolved inorganic and organic solids like carbohydrates, lignin, fat and protein, synthetic soap and detergent, heavy metals, phyto hormones, antibiotics etc. (Pereira et al., 2014). Thus, we may assume

*Corresponding author: sanakray@csmcri.res.in 
that treatment of municipal waste water has the capacity to provide water, energy and nutrient after operation and treatment (Qadir et al., 2020).

The most important thing is to identify an excellent, pocket friendly and green technologywith high pollutant removal efficiency and productivity. Although there are various methods like chemical, biological and physical methods, but no method is approachable solely for the treatment. Constructed wetland (CW), an engineered advanced ecological system thatpractices biogeochemical processes, to treat wastewater with no harmful impact on environment. The mechanisms that occurred during the operations are sedimentations and filtration (coming under physical processes), precipitation and adsorption (coming under chemical processes) and microbial remediation, phyto remediation, phyto adsorption and natural die off (coming under biological processes) (CPCB, 2019). Advantages like using less space for the construction of $\mathrm{CW}$, simple operation and maintenance, low capital cost, no chemical use, less sludge production, a little electricity consumption, sustainability, high pollutant removal potential etc. are playing the key roles for making this system suitable for municipal wastewater management (M. Ali et al., 2018; Corbella \& Puigagut, 2018).

The performance of the system depends upon various factor like geographical location of the system, meteorological parameter, substrate, hydraulic gradient, residence time of effluent, flow rate of effluent, water depth, feeding mode, plant species, microbial growthetc. The engineered system has the potentiality to treat the pollutant like TSS, TDS, total nitrogen, total phosphorous, BOD, COD, heavy metals, microbial community and emerging contaminants etc.(Abou-Elela et al., 2017; Ji et al., 2022; Shukla et al., 2021).

Constructed wetlands can be categorized in various forms on the basis of types of hydrology, vegetation and flow of the water. On the basis of hydrology and flow type they are classified as subsurface flow and free surface flow CWand subsurface flow CW again classified as horizontal and vertical flow CW respectively. Vegetation's(potential to survive in worse climatic situations, having fighting nature for waterlogged-anoxic as well as hyper-eutrophic situations) play the most important role for removal of pollutants in the CW (Rahman et al., 2020). Thus, on the basis of vegetation CWs are also categorized into submerged, floating leaved, free floating and emergent macrophytes types (Vymazal, 2010).

\section{Constructed wetland for Municipal wastewater}

Various designs like horizontal sub-surface flow CW, Vertical sub-surface flow CW, Hybrid CW, Multi stage $\mathrm{CW}$ etc. and some modification and addition of advanced technologies are there to treat and recover energy, nutrient etc. from municipal wastewater and make fit that treated water quality for reuse purposes.Overview of various constructed wetlands treating municipal wastewater were shown in Table 1.

A Comparative study was performed by (Masi et al., 2013) to evaluate the performance of multistage constructed wetland. Thus, they designed a four stage $\mathrm{CW}$ at Dicomono in Italy and a three stage CW at Chorfech in Tunisia. By evaluating the performance, they concluded that multistage that means four stage $\mathrm{CW}$ was capable to treat the municipal wastewater significantly with removal efficiency $86 \%, 60 \%$, 43\%, 89\%, 89\%, 76\% for the Organic Load, Total Nitrogen (TN), Total Phosphorus (TP), Total Suspended Solids (TSS) and Ammonium (NH4) respectively and reduction in the pathogen concentration was achieved up-to 4-5 logs.

A full scale hybrid Constructed wetland was designed by (Z. Ali et al., 2018) to treat the municipal wastewater and applied that treated water for irrigation purposes. The design of the hybrid constructed wetland was comprised of a vertical sub-surface flow constructed wetland and five phyto-treatment ponds. They concluded that after treatment through VSSFCW the pollutants concentration decreased significantly still then the value of pollutant like phosphate, cadmium, chromium and potassium was not found to be under standard value fixed for the irrigation purposes. Thus, again the treated water was passed through the phyto-treatment ponds and they got success to match the water quality with the standard value prescribed for the irrigation purposes.

Kickuth Type Constructed wetlands are used especially in European countries in which cohesive soil is used as a medium for the vegetation growth and filtration unit(CPCB, 2019). The municipal wastewater treatment for 10 year was analyzed by using sub-surface flow Kickuth type constructed wetland in Poland. During study (Mucha et al., 2018) 
Table 1: Overview of various constructed wetlands treating municipal wastewater.

\begin{tabular}{|c|c|c|c|c|c|c|c|}
\hline Wetland type & Scale & Substrates type & $\begin{array}{l}\text { Plants } \\
\text { type }\end{array}$ & Flow Rate & $\begin{array}{c}\text { Feeding } \\
\text { mode }\end{array}$ & Pollutant removal (\%) & Source \\
\hline $\begin{array}{l}\text { Hybrid CW (VSSFW + } \\
\text { Phyto-treatment Pond) }\end{array}$ & Full Scale & $\begin{array}{l}\text { coarse sand }(1.25-2.0 \\
\text { mm }), \text { medium gravel } \\
(6-15 \mathrm{~mm}), \text { coarse } \\
\text { gravel }(35-60 \mathrm{~mm}), \\
\text { cobbles }(65-98 \mathrm{~mm}), \\
\text { and broken brick pieces } \\
(101-152 \mathrm{~mm})\end{array}$ & $\begin{array}{l}\text { Phragmitesaustral } \\
\text { is, Canna indica, } \\
\text { Typhalatifolia }\end{array}$ & & Continues & $\begin{array}{l}\mathrm{COD}=56.03 \\
\mathrm{BOD}=57.02\end{array}$ & $\begin{array}{l}\text { (Z. Ali et } \\
\text { al., 2018) }\end{array}$ \\
\hline $\begin{array}{l}\text { Sub Surface Flow } \\
\text { Kickuth Type CW }\end{array}$ & Full Scale & $\begin{array}{l}\text { Humus straw } \\
\text { local soil(Loamy Soil) }\end{array}$ & $\begin{array}{l}\text { Phragmitesaustral } \\
\text { is }\end{array}$ & $116 \mathrm{~m}^{3} / \mathrm{d}$ & Continues & $\begin{array}{l}\mathrm{TN}=74.3 ; \mathrm{NH}_{4}-\mathrm{N} \\
=62.1 ; \\
\mathrm{NO}_{3}-\mathrm{N}=77.7 ; \\
\mathrm{TP}=29.6 ; \mathrm{PO}_{4}-\mathrm{P}= \\
37.4 ; \\
\mathrm{COD}=46.7\end{array}$ & $\begin{array}{l}\text { Barco \& } \\
\text { Borin, } \\
2017)\end{array}$ \\
\hline $\begin{array}{l}\text { Hybrid CW (HSSF- } \\
\text { CW + FTW) }\end{array}$ & Full Scale & $\begin{array}{l}\text { River washed Gravel } \\
(8 \mathrm{~mm}\end{array}$ & $\begin{array}{l}\text { Phragmitesaustral } \\
\text { is, } \\
\text { Iris pseudacorus }\end{array}$ & $200 \mathrm{~m} 3 / \mathrm{d}$ & Continues & $\begin{array}{l}\mathrm{BOD}_{5}=91.60 \\
\mathrm{COD}=89.82 \\
\mathrm{TSS}=95.62 \\
\mathrm{TN}=17.44 \\
\mathrm{TP}=23.07\end{array}$ & $\begin{array}{l}\text { (Mucha et } \\
\text { al., 2018) }\end{array}$ \\
\hline MFC-CW & Lab Scale & $\begin{array}{l}\text { gravels }(5-12 \mathrm{~mm}) \\
\text { sands }(0.5-2 \mathrm{~mm})\end{array}$ & Water Hycinth & $5 \mathrm{~m}^{3} / \mathrm{d}$ & & $\begin{array}{l}>95 \text { for (SS, BOD5 } \\
\text { and N-NH4+) } \\
>90 \text { for (COD and } \\
\text { PO4-P ) } \\
>5 \text { log units of } \\
\text { coliform } \\
\text { and } 100 \text { helminth egg }\end{array}$ & $\begin{array}{l}\text { (Torrens } \\
\text { et al., } \\
\text { n.d.) }\end{array}$ \\
\hline Multistage CW & Full Scale & $\begin{array}{l}\text { Silex granite river } \\
\text { gravel }\end{array}$ & $\begin{array}{l}\text { Phragmites } \\
\text { Typha }\end{array}$ & $5 \mathrm{~m}^{3} / \mathrm{d}$ & Batch & $\begin{array}{l}>95 \text { for }\left(\mathrm{SS}, \mathrm{BOD}_{5}\right. \\
\left.\text { and } \mathrm{N}^{-\mathrm{NH}_{4}^{+}}\right) \\
>90 \text { for }(\mathrm{COD} \text { and } \\
\left.\mathrm{PO} 4-{ }_{\mathrm{p}}\right) \\
>5 \mathrm{log} \text { units of } \\
\text { coliform } \\
\text { and } 100 \text { helminth } \\
\text { egg }\end{array}$ & $\begin{array}{l}\text { (Torrens } \\
\text { et al., } \\
\text { n.d.) }\end{array}$ \\
\hline VSSF-CW & Pilot Scale & Sand gravel & Cyperus Papyrus & $0.6 \mathrm{~m}^{3} / \mathrm{d}$ & Batch & $\begin{array}{l}\mathrm{TP}= \\
50 \mathrm{ammoniacalnitrog} \\
\text { en }=(69.69), \mathrm{BOD} \\
=(69.87), \mathrm{COD}= \\
80.69, \\
\quad \text { total coliforms }= \\
98.08 \\
\text { fecal coliforms }= \\
95.61\end{array}$ & $\begin{array}{l}\text { (García- } \\
\text { Ávila, } \\
2020)\end{array}$ \\
\hline VSSF-CW & Pilot scale & $\begin{array}{l}\text { Gravel pozzolan } \\
\text { sand }\end{array}$ & $\begin{array}{l}\text { Phragmitesaustral } \\
\text { is }\end{array}$ & $60 \mathrm{~L} / \mathrm{m}^{2} / \mathrm{d}$ & Batch & $\begin{array}{l}\mathrm{COD}=91 ; \\
\text { polyphenols }=89, \\
\mathrm{PO}_{4}^{3-}=94 ; \mathrm{SO}_{4}^{2 \cdot}= \\
58 ; \mathrm{NO}_{2}^{2}=92, \text { and } \\
\mathrm{NH}_{4}^{+}=95\end{array}$ & $\begin{array}{l}\text { El } \\
\text { Ghadrao } \\
\text { ui et al., } \\
2020)\end{array}$ \\
\hline
\end{tabular}

observed that the efficiency of the wetland increased up-to 10 years from the initial year then the efficiency decreased and many problems like beds clogging evolved. They also observed that BOD, COD and TSS removal was quite satisfactory and performance slowed down after 12 years. Whereas, the system was unable to treat TPand TN significantly from the beginning of the study.

A study was done by (Barco \& Borin, 2017) to treat the municipal wastewater through a hybrid constructed wetland. During study they changed the macrophytes 
of the existing hybrid constructed wetland. The HCW was the combination of HSSF-CW (Horizontal Subsurface Flow Constructed wetland) and FTW (Floating treatment Wetland). In past the existing HCW was planted with the vegetation like Prunus laurocerasus, Laurus nobilis, Elaeagnus angustifolia and Pittosporum spp etc. which were not wetland species and did not have capacity to treat the wastewater due to short root system and controlled evapotranspiration rates. They observed noteworthy performance of the HCW by changing the vegetation to Phragmites australis, Iris pseudacorus.

A coupled microbial fuel cell- constructed wetland was tested in lab scale for energy harness by treating municipal wastewater (Tao et al., 2020). The integrated CW was installed inside a glass column having diameter $30 \mathrm{~cm}$ and height $55 \mathrm{~cm}$. The column was packed with gravels of different size from bottom to top. The anode was inserted in the middle of the packing layer and cathode was inserted in the upper layer of the column where air and water boundary were occurred. To provide oxygen facility the upper layer was planted with water hyacinth. They found xylan as the best carbon source for microbial fuel cell. During their experiment they concluded that the mixture of glucose and xylan (40: 60) was the excellent carbon source to achieve TN removal up-to $88.78 \pm 3.98 \%$ with average power density $3.8 \mathrm{~mW} / \mathrm{m} 2$.

A multistage constructed wetland consisting of two stages of vertical flow and one stage of horizontal flow was constructed by (Torrens et al., n.d.)to treat the municipal wastewater for using that treated water in irrigation purposes in Senegal, which is a hot and arid climate zone. During this study they observed that uncrushed gravel and Typha played major role in treating wastewater and pollutant removal. They conclude that as the treated water quality lied under the standard value given for the agricultural purposes, which was a bless in the area like Senegal.

Treatment of municipal wastewater by vertical flow constructed wetland has been studied worldwide. Choosing vegetation during the wastewater treatment through constructed wetland is one of the important and unavoidable part as it influences the treatment activity. Thus, (García-Ávila, 2020) performed a comparative study in between two plant species named Phragmites Australis and Cyperus Papyrus. They evaluated by analysing physical, chemical and biological parameters for three consecutive months that Cyperus Papyrus was very much potential to treat the municipal wastewater with significant removal efficiency.

A pilot scale study was done to treat the olive oil and municipal wastewater mixture through a VFCW. The system was comprised of PVC tank of height $0.60 \mathrm{~m}$ and surface area $0.24 \mathrm{~m} 2$. The tank was filled by $30 \mathrm{~cm}$ of sand $(0.25 / 0.40 \mathrm{~mm})$ after that $10 \mathrm{~cm}$ of pozzolan $(5 / 20 \mathrm{~mm})$ and $10 \mathrm{~cm}$ of gravel $(20 / 40 \mathrm{~mm})$ from bottom to top. During the study pozzolan was introduced as a filing medium to enhance the removal efficiency for pollutants present in the wastewater mixture. They found that the system was capable to remove total phenolic compound (hydroxytyrosol, tyrosol, caffeic acid, P-caumaric acid, and cinnamic acid) present in the mixture only because of pozzolan. They also observed the quality of treated water matched with the Moroccan irrigation standard and could be applied for irrigation of cereal, industrial and fodder crops, pastures, and plantations trees.

\section{CONCLUSION}

This 21st century is a crucial period for all the inhabitants of the mother earth. Our changing life style, reckless behavior for the nature and her properties has turned our healthy surroundings intovenomous one. In our above discussion we have discussion we have discussed on wastewater and its treatment in a sustainable way. Taking sustainable treatment into account we have only focused on the pocket and eco-friendly technology that is constructed wetland. From the above discussion we may conclude that for municipal wastewater treatment, the major contributor of water pollution, we should follow constructed wetland. Our study showed that among various constructed wetland the excellent one with greater removal rate is multistage hybrid constructed wetland. Besides design, selection of substrate and vegetation, major part constructed wetland depends on the locality and geographical condition. The best and most important matter is that after treatment of wastewater in can be reused for various purposes which that we have mentioned above. In-addition to it energy harness is also possible by integration MFC with constructed wetland. For potable water we may treat that constructed wetland treated water through various advanced oxidation method like UV radiation, ozonation or membrane (nano, micro, reverse- 
osmosis). Overall discussion proved that constructed wetland is the best solution for municipal wastewater treatment from economic, environment, aesthetic, and space requirement aspects.

\section{ACKNOWLEDGEMENTS}

Authors sincerely acknowledge Director, CSIRCSMCRI, for providing infrastructural facilities. This work was supported by the Science and Engineering Research Board (GOI) [The project grant/file no. SRG/2019/001803].

\section{REFERENCE}

1. Abou-Elela, S. I., Elekhnawy, M. A., Khalil, M. T., \& Hellal, M. S. (2017). Factors affecting the performance of horizontal flow constructed treatment wetland vegetated with Cyperus papyrus for municipal wastewater treatment. International Journal of Phytoremediation, 19(11), 1023-1028. https://doi.org/10.1080/ 15226514.2017.1319327.

2. Ali, M., Rousseau, D. P. L., \& Ahmed, S. (2018). A full-scale comparison of two hybrid constructed wetlands treating domestic wastewater in Pakistan. Journal of Environmental Management, 210, 349-358. https://doi.org/10.1016/ j.jenvman.2018.01.040

3. Ali, Z., Mohammad, A., Riaz, Y., \& Quraishi, U. M. (2018). Treatment efficiency of a hybrid constructed wetland system for municipal wastewater and its suitability for crop irrigation. International Journal of Phytoremediation, 20(11), 1152-1161. https://doi.org/10.1080/ 15226514.2018.1460311

4. Barco, A., \& Borin, M. (2017). Treatment performance and macrophytes growth in a restored hybrid constructed wetland for municipal wastewater treatment. Ecological Engineering, 107, 160-171. https://doi.org/ 10.1016/ j.ecoleng.2017.07.004.

5. Corbella, C., \& Puigagut, J. (2018). Improving domestic wastewater treatment efficiency with constructed wetland microbial fuel cells: Influence of anode material and external resistance. Science of the Total Environment, 631-632, 1406-1414. https://doi.org/10.1016/ j.scitotenv.2018.03.084.

6. CPCB. (2019). Manual on Constructed Wetland as an Alternative Technology for Sewage Management in India (p. 207).
7. El Ghadraoui, A., Ouazzani, N., Ahmali, A., El Mansour, T. E. H., Aziz, F., Hejjaj, A., Del Bubba, M., \& Mandi, L. (2020). Treatment of olive mill and municipal wastewater mixture by pilot scale vertical flow constructed wetland. Desalination and Water Treatment, 198, 126-139. https://doi.org/10.5004/dwt.2020.26009.

8. García-Ávila, F. (2020). Treatment of municipal wastewater by vertical subsurface flow constructed wetland: Data collection on removal efficiency using Phragmites Australis and Cyperus Papyrus. Data in Brief, 30. https://doi.org/ 10.1016/j.dib.2020.105584.

9. Gilmour, D. J., \& Zimmerman, W. B. (2020). Microbubble intensification of bioprocessing. In Advances in Microbial Physiology (1st ed., Vol. 77). Elsevier Ltd. https://doi.org/10.1016/ bs.ampbs.2020.07.001.

10. Ji, Z., Tang, W., \& Pei, Y. (2022). Constructed wetland substrates: A review on development, function mechanisms, and application in contaminants removal. Chemosphere, 286(P1), 131564. https://doi.org/10.1016/ j.chemosphere. 2021.131564.

11. Masi, F., Caffaz, S., \& Ghrabi, A. (2013). Multistage constructed wetland systems for municipal wastewater treatment. Water Science and Technology, 67(7), 1590-1598.

12. Mucha, Z., Wójcik, W., Jóźwiakowski, K., \& Gajewska, M. (2018). Long-term operation of Kickuth-type constructed wetland applied to municipal wastewater treatment in temperate climate. Environmental Technology (United Kingdom), 39(9), 1133-1143. https://doi.org/ 10.1080/09593330.2017.1323014.

13. Pereira, L. S., Duarte, E., \& Fragoso, R. (2014). Water Use: Recycling and Desalination for Agriculture. Encyclopedia of Agriculture and Food Systems, 5, 407-424. https://doi.org/ 10.1016/B978-0-444-52512-3.00084-X.

14. Qadir, M., Drechsel, P., Jiménez Cisneros, B., Kim, Y., Pramanik, A., Mehta, P., \& Olaniyan, O. (2020). Global and regional potential of wastewater as a water, nutrient and energy source. Natural Resources Forum, 44(1), 40-51. https://doi.org/10.1111/1477-8947.12187. 
15. Rahman, M. E., Halmi, M. I. E. Bin, Samad, M. Y. B. A., Uddin, M. K., Mahmud, K., Shukor, M. Y. A., Abdullah, S. R. S., \& Shamsuzzaman, S. M. (2020). Design, operation and optimization of constructed wetland for removal of pollutant. International Journal of Environmental Research and Public Health, 17(22), 1-40. https://doi.org/ 10.3390/ijerph17228339.

16. Shukla, R., Gupta, D., Singh, G., \& Mishra, V. K. (2021). Performance of horizontal flow constructed wetland for secondary treatment of domestic wastewater in a remote tribal area of Central India. Sustainable Environment Research, 31(1). https://doi.org/10.1186/s42834-02100087-7.
17. Tao, M., Guan, L., Jing, Z., Tao, Z., Wang, Y., Luo, H., \& Wang, Y. (2020). Enhanced denitrification and power generation of municipal wastewater treatment plants (WWTPs) effluents with biomass in microbial fuel cell coupled with constructed wetland. Science of the Total Environment, 709, 136159. https://doi.org/ 10.1016/j.scitotenv.2019.136159.

18. Torrens, A., Varga, D. De, \& Ndiaye, A. K. (n.d.). Innovative Multistage Constructed Wetland for Municipal Wastewater Treatment and Reuse for.

19. Vymazal, J. (2010). Constructed wetlands for wastewater treatment. Water (Switzerland), 2(3), 530-549. https://doi.org/10.3390/w2030530. 